\title{
INFRASTRUCTURAL RESOURCE PLANNING DYNAMICS AND PERFORMANCE OF UPGRADED EXTRA-COUNTY SCHOOLS TO NATIONAL STATUS IN WESTERN KENYA COUNTIES
}

\author{
Violet Wekesa' ${ }^{1 \mathrm{i}}$, \\ Lydia Kipkoech ${ }^{2}$ \\ ${ }^{1}$ Doctoral Candidate, \\ Department of Educational Management, \\ University of Eldoret, \\ Kenya \\ ${ }^{2} \mathrm{PhD}$, Lecturer, \\ Department of Educational Management, \\ University of Eldoret, \\ Kenya
}

\begin{abstract}
:
Infrastructure resource planning is important to ensure provision of quality education in public secondary schools. When the extra county public secondary schools were upgraded to national status, it was expected that the increased enrolment would match with expansion of existing facilities. This paper addresses the infrastructural resource planning dynamics and performance of upgraded schools in western Kenya. The study adopted a descriptive research design; the target population were 263 and 8 principals from teachers in the 8 upgraded national schools. The sample size was 156 respondents purposively sampled for principals and heads of departments, while teachers were sampled using random sampling technique. Data was collected using questionnaires, interview schedule and observation checklist. The collected data was analyzed using descriptive statistics. Research data showed that Infrastructural resources planning dynamics had no significant $(\mathrm{r}=0.063, \mathrm{p}=0.432)$ with performance of the upgraded schools to national level. The result found out that the increased enrolment did not match with increased infrastructure facilities. The paper concludes that performance of students in KCSE examinations was negatively affected as the available infrastructural facilities could not accommodate high number of learners admitted hence affecting effective teaching and learning process. The study recommends that Ministry of Education should increase allocation to upgraded national schools to expand their infrastructure and upgraded schools board of management should mobilise financial resources to enable them to put up new and expand the existing facilities for quality secondary education.
\end{abstract}

i Correspondence: violetwekesa37@gmail.com 
Keywords: planning, dynamics, upgraded, national, extra-county, performance

\section{Introduction}

Physical infrastructural facilities in secondary schools involve school buildings, classrooms, library, laboratories, toilet facilities, offices and other materials and infrastructures that would likely motivate students towards conducive learning (Lasoi et al., 2017). Infrastructural facilities are germane to effective learning and academic performance of students (Owoeye \& Olatunde, 2011) in secondary schools. Availability of adequate infrastructural resources in terms of proper and standard facilities enhances the effectiveness of schools, as these are basic things that facilitate provision of quality education. Proper planning, provision and utilization of these learning facilities are the responsibility of school management (National Policy on Education, 2012). This means that the available infrastructural facilities need to match the number of student enrolled (Ogunniyi, et al., 2018). For instance, one classroom should accommodate between 35-45 learners according to Ministry of Education Guidelines. Reduced class size motivates teachers to effective teaching due to standardised student participation (Wakoli \& Kisilu, 2019). The work of ensuring this is attained is vested by Education Act (2013) to secondary school Board of Management (BOM).

Proper infrastructure facilities planned and constructed in school allows teachers and students to focus most of their time and energy on learning as there are no disruptions or congestions. Waweru (2005) observed that appearance of adequate infrastructural facilities in school is an important source of inspiration and motivation for members of the school community. The development and maintenance of infrastructural facilities in secondary schools by community, parents and sponsors should be encouraged (Andiema, Kemboi \& M'mbone, 2013; Republic of Kenya, 2015). This is because lack of such infrastructural facilities interferes with the effective learning process (Wekesa \& Kitainge, 2020). This paper investigates how upgraded extra county schools to national schools' infrastructural facilities changed to match their student population through proper planning strategies in western Kenya. This is because review of previous literature has shown that the performance of upgraded new national schools have been disappointing with few maintaining the stellar performance before they were upgraded (Regional Director of Education, 2018). Indeed, infrastructural resources enhance the conducive environment that promotes effective teaching and learning in classrooms. Studies conducted on the effect of the infrastructure provision on teacher motivation attest the fact that school environment that is not conducive to teaching may lead to low motivation hence underperformance by students in examinations (Chimombe, 2011). Provision of adequate infrastructural learning facilities in secondary schools enhances the quality and relevance of imparting skills to learners (Lumuli, 2009). Lucas and Mbiti (2014) linked performance in examinations to the state of teaching and learning resources in schools. They notes that students from poor backgrounds performed poorly in the examinations because these students were learning in institutions that had dilapidated 
infrastructure associated with inadequate funds provision by government and poor planning by BOM. Furthermore, lack of adequate infrastructural facilities also affects teacher morale in teaching (Wekesa \& Kitainge, 2012) and learning leading to poor performance of students in examinations. This paper describes the relationship between infrastructural resource planning dynamics and performance of upgrade extra county schools to national status in Western Kenya.

\section{Statement of the Problem}

Data from upgraded extra county schools to national level in western Kenya have recorded decreased performance in various fronts since they were upgraded (Western Kenyan Counties Director of Education Offices, 2018). The intention of MOE to upgraded extra county schools to national status was informed by the need to ensure all students who successful passed primary education examinations (KCPE) had a chance to join national schools around the country. Analysis of performance data of the upgraded national schools in the last five years has been decreasing (Wekesa \& Kitainge, 2020). As it was expected, the upgrading of these schools resulted to increased enrolment of students (some even double they used to take) and this called for the Ministry of Education and BOM to consider expanding the existing facilities. Research examining the linkage between infrastructural resource dynamics and performance of these upgraded schools is inadequate. The paper therefore looks at the infrastructural planning dynamics and performance of upgraded extra county public secondary schools to national status in western, Kenya.

\subsection{Hypotheses}

The study had the following hypothesis

$\mathrm{H}_{0}$ : There is no significant relationship between infrastructural resource dynamics and performance of upgraded secondary schools in Western Kenya Counties.

$\mathrm{H}_{\mathrm{a}}$ : There is a significant relationship between infrastructural resource dynamics and performance of upgraded secondary schools in Western Kenya Counties.

\subsection{Review of Literature}

Infrastructural learning resources include classrooms, laboratories, libraries, playing fields, dormitories, latrines, administration blocks and water storage facilities that should be provided in secondary schools for quality education (Lucas \& Mbiti, 2014).

Library is an essential factor in teaching-learning process. It forms one of the most important educational services. The educational process functions in a world of books. According to Okumbe (2011), a library must be up-to-date and at the same time allow access to older materials. Owoeye and Olatunde (2011), noted that the availability of the classrooms contribute to good academic performance as they enhance effective teachinglearning activities. Classrooms, offices, assembly halls, laboratories and staff quarters are needed and should be adequate in number and they should all be in good conditions for 
schools to function properly. According to Ogada and Simatwa (2016), reported schools that lacked adequate classrooms held their lessons outside or under trees. During bad weather, such lessons were postponed or were never held altogether. This interfered with syllabus coverage; students from such schools did not perform well in examination. Ogunniyi et al. (2018) said there is a general consensus among science educators that the laboratory occupies a central position in science instruction. According to Ongowo and Indoshi (2013) laboratory work, stimulates learners' interests as they are made to personally engage in useful scientific activities and experimentation and it promotes that science is not only products. Owoeye and Olatunde (2011) have shown that schools with well-equipped laboratories have better results in the school certificate science examinations than those that are ill equipped.

Ahawo (2009) noted in her study in upgraded national schools in Kisumu East Sub County on the importance of a well-equipped laboratory to enhance performance in science subjects, which are compulsory for every Kenyan student at Kenya Certificate of Secondary Education examination. Ahawo noted that most laboratories in the Upgraded Extra County National Schools in Sub County were ill equipped because of insufficient funds and high cost of laboratory equipment. This affected students' performance negatively since the students did not have many practical lessons and some students were meeting some apparatus for the first time in the national examinations. Mobegi et al. (2010) suggests that the question of equipment demands that schools should possess not only what is necessary but also what is modern and up to date if good quality of work must be done. This study seeks to establish the status of the laboratory and laboratory equipment in upgraded extra county national schools in Western Kenya Counties today and establish it influence on student academic achievement in the science subjects today. Best (2005) argued that effective facilities management contributed to the success of every student in every school in the United States. He further recommended that implementing policies that resulted in high quality high performing well designed and well-maintained school facilities had a direct and indirect impact on teaching and learning process, therefore this study seeks to determine preparedness of upgraded national schools for effective implementation of the school curriculum. Waweru and Orodho (2015) observe that principals should make periodic evaluation of school buildings as well as grounds to ensure safety of the school. Okumbe (2011) adds that principals need to upgrade facilities in the event of new knowledge and technology such as use of computers, laboratory equipment such as microscopes. Ogada and Simwatwa (2016) noted that parents through the initiative of parents' association project should finance school physical facilities such as boarding facilities, electricity, water, telephone, transport, purchase and maintenance of school vehicles, general repair and construction of buildings such as classrooms, laboratories, staff houses and hostels upgraded extra county national schools are ill equipped to facilitate proper implementation of the school curriculum in this schools. Resource mobilization is imperative for the success of upgraded national schools. Resources play a significant role in enabling provision of national education services in the country. Upgraded national schools require specialized 
human, materials and physical resources. According to Ogot (2008), Kenya's attempt to fund national education specifically in targeted upgraded national schools has been made with challenges. This study will seek to determine whether the upgraded national schools are well funded by the government to determine whether they can be able to purchase additional land for expansion since the irregularity of the funds disbursements has been reported to be causing anxiety upgraded county national schools. There is need for a study on the nature of resource allocation to upgraded national schools and decision-making capacity of the school to meet the student's needs effectively and efficiently. This study will seek to determine whether available school resources affected the performance of the upgraded national schools in adapting to their current status. In view of these different and conflicting findings, the study seeks to assess the state of laboratories and preparedness of national schools in Western Kenya Counties.

\section{Materials and Methods}

The study conducted in four Western Kenya Counties; Vihiga, Bungoma, Kakamega and Busia. There are eight upgraded national schools with an estimated student population of 5600 and 270 members of the teaching staff. The study utilised mixed method research paradigm with a descriptive survey research design. The eight upgraded extra county schools to national status were: Lugulu Girls, Bunyore Girls, Friends School Kamusinga, Butula Boys, Kakamega Boys, Butere Girls, Kolanya Girls and Chavakali Boys The target population comprised of 8 principals and 295 teachers. The final sample size for the study involved 170 teachers and 8 principals. The teachers were selected using systematic sampling and principals using purposive sampling. Questionnaires, interview schedule and document analysis were used to collect data. Quantitative data will be coded, entered and analysed with the help of SPSS Version 23.0 computer software. Analysis of data was performed using frequencies, percentages, means and standard deviation. Karl Pearson Correlation was used to test hypothesis at 95.0\% confidence level. Qualitative data was analysed using thematic content analysis.

\section{Results and Discussions}

The teachers were asked to indicate the degree to which they agreed or disagreed with various statements on how infrastructure was provided as a result of their upgrade. The findings are summarised in Table 1. 
Table 1: Infrastructure Dynamics in Upgraded National Schools

\begin{tabular}{|c|c|c|c|c|c|c|c|}
\hline Infrastructure resource & SD & D & UD & $\mathbf{A}$ & SA & $\mathbf{M}$ & SD \\
\hline $\begin{array}{l}\text { The library facility has been } \\
\text { expanded to accommodate all } \\
\text { students enrolled after } \\
\text { upgrading }\end{array}$ & $\begin{array}{c}98 \\
(62.0 \%)\end{array}$ & $\begin{array}{c}30 \\
(19.0 \%)\end{array}$ & $\begin{array}{c}14 \\
(8.8 \%)\end{array}$ & $\begin{array}{c}10 \\
(6.3 \%)\end{array}$ & $\begin{array}{c}6 \\
(3.8 \%)\end{array}$ & 1.7089 & 1.10761 \\
\hline $\begin{array}{l}\text { More classes have been built to } \\
\text { accommodate more students } \\
\text { being admitted after upgrading }\end{array}$ & $\begin{array}{c}72 \\
(45.6 \%)\end{array}$ & $\begin{array}{c}40 \\
(25.3 \%)\end{array}$ & $\begin{array}{c}10 \\
(6.3 \%)\end{array}$ & $\begin{array}{c}22 \\
(13.9 \%)\end{array}$ & $\begin{array}{c}14 \\
(8.9 \%)\end{array}$ & 2.1519 & 1.36460 \\
\hline $\begin{array}{l}\text { Laboratories have been } \\
\text { constructed i.e. science lab, } \\
\text { computer lab, workshops to aid } \\
\text { in practical teaching approaches } \\
\text { after upgrading }\end{array}$ & $\begin{array}{c}88 \\
(55.7 \%)\end{array}$ & $\begin{array}{c}36 \\
(22.8 \%)\end{array}$ & $\begin{array}{c}20 \\
(12.7 \%)\end{array}$ & $\begin{array}{c}10 \\
(6.3 \%)\end{array}$ & $\begin{array}{c}4 \\
(2.5 \%)\end{array}$ & 1.7722 & 1.05817 \\
\hline $\begin{array}{l}\text { Play grounds have been } \\
\text { Expanded to include different } \\
\text { kind of sports to ensure } \\
\text { students participate in co- } \\
\text { curricular activities after } \\
\text { upgrading }\end{array}$ & $\begin{array}{c}96 \\
(60.8 \%)\end{array}$ & $\begin{array}{c}30 \\
(19.0 \%)\end{array}$ & $\begin{array}{c}18 \\
(11.4 \%)\end{array}$ & $\begin{array}{c}8 \\
(5.1 \%)\end{array}$ & $\begin{array}{c}6 \\
(3.8 \%)\end{array}$ & 1.7215 & 1.09354 \\
\hline $\begin{array}{l}\text { Dormitories have been } \\
\text { increased and expanded to } \\
\text { accommodate more students } \\
\text { after upgrading }\end{array}$ & $\begin{array}{c}86 \\
(54.4 \%)\end{array}$ & $\begin{array}{c}34 \\
(21.5 \%)\end{array}$ & $\begin{array}{c}18 \\
(11.4 \%)\end{array}$ & $\begin{array}{c}12 \\
(7.6 \%)\end{array}$ & $\begin{array}{c}8 \\
(5.1 \%)\end{array}$ & 1.8734 & 1.18770 \\
\hline $\begin{array}{l}\text { Washrooms/latrines have been } \\
\text { constructed and expanded to } \\
\text { improve on sanitation after } \\
\text { upgrading }\end{array}$ & $\begin{array}{c}78 \\
(49.4 \%)\end{array}$ & $\begin{array}{c}30 \\
(19.0 \%)\end{array}$ & $\begin{array}{c}28 \\
(17.7 \%)\end{array}$ & $\begin{array}{c}16 \\
(10.1 \%)\end{array}$ & $\begin{array}{c}6 \\
(3.8 \%)\end{array}$ & 2.0000 & 1.19447 \\
\hline $\begin{array}{l}\text { The dining hall has been } \\
\text { expanded and built to improve } \\
\text { students services after } \\
\text { upgrading }\end{array}$ & $\begin{array}{c}104 \\
(65.8 \%)\end{array}$ & $\begin{array}{c}20 \\
(12.7 \%)\end{array}$ & $\begin{array}{c}24 \\
(15.2 \%)\end{array}$ & $4(2.5 \%)$ & $\begin{array}{c}6 \\
(3.8 \%)\end{array}$ & 1.6582 & 1.06939 \\
\hline $\begin{array}{l}\text { Enough lockers, tables and } \\
\text { other classroom facilities have } \\
\text { been increased since upgrading } \\
\text { to national school to aid in } \\
\text { learning process }\end{array}$ & $\begin{array}{c}76 \\
(48.1 \%)\end{array}$ & $\begin{array}{c}34 \\
(21.5 \%)\end{array}$ & $\begin{array}{c}28 \\
(17.7 \%)\end{array}$ & $\begin{array}{c}12 \\
(7.6 \%)\end{array}$ & $\begin{array}{c}8 \\
(5.1 \%)\end{array}$ & 2.0000 & 1.19447 \\
\hline $\begin{array}{l}\text { Our school land has been } \\
\text { expanded, purchases or being } \\
\text { put to use (non-used land) after } \\
\text { upgrading to national status to } \\
\text { ensure expansion of facilities }\end{array}$ & $\begin{array}{c}78 \\
(49.4 \%)\end{array}$ & $\begin{array}{c}46 \\
(29.1 \%)\end{array}$ & $\begin{array}{c}18 \\
(11.4 \%)\end{array}$ & $\begin{array}{c}6 \\
(3.8 \%)\end{array}$ & $\begin{array}{c}10 \\
(6.3 \%)\end{array}$ & 1.8861 & 1.15088 \\
\hline $\begin{array}{l}\text { The school has purchased bus } \\
\text { or added another one to ease } \\
\text { transport of students during } \\
\text { field trips after upgrading }\end{array}$ & $\begin{array}{c}74 \\
(46.8 \%)\end{array}$ & $\begin{array}{c}40 \\
(25.3 \%)\end{array}$ & $\begin{array}{c}14 \\
(8.9 \%)\end{array}$ & $\begin{array}{c}18 \\
(11.4 \%)\end{array}$ & $\begin{array}{c}12 \\
(7.6 \%)\end{array}$ & 2.0759 & 1.30430 \\
\hline Composite values & & & & & & 1.8848 & 1.1725 \\
\hline
\end{tabular}

Key: SD-Strongly Disagree, D-Disagree, U-Undecided, A-Agree, SA-Strongly Agree, M-Means and SDStandard Deviation 
Findings shows that majority 98 (62.0\%) of teachers strongly disagreed that their library building was expanded or new one constructed to accommodate all students who were enrolled after upgrading. Most teachers appeared to disagree with the statements $(\mathrm{M}=1.70$ and $\mathrm{SD}=1.10)$. This implies that the library facilities in most upgraded schools experienced congestions and therefore learners are not in a position to conduct their own private studies, research or reading as the space and volume of books are inadequate. In line with the study result, Omego and Simatwa (2015) established that inadequate library meant that limited source of information for teachers' preparation and students' personal study in the Kisumu East sub-county hence accounting for the weak performance of the sub-county.

Close to half $72(45.6 \%)$ of teachers also strongly disagreed that additional classes were built to accommodate more students who were admitted after their institutions were upgraded. This shows that incidents of overcrowding in class (with more than 50 students) are common across these schools as the carrying capacity of the school is less compared to the number of learners who are enrolled. In agreement with the study findings, Omego and Simatwa (2015) found out that classrooms were essential for effective learning and teaching to take place. In a situation where the classrooms are inadequate learning and teaching is done outside the classroom, this becomes very inconveniencing as they found in Kisumu East Sub County. The study found out that majority of teachers also strongly disagreed $88(55.7 \%)$ that new laboratories were constructed after the upgrade to aid in practical teaching. During researcher visit to some of the schools, it was found out that there were laboratories under construction and some of them had delayed in being completed due to inadequacy of funds. Even during interview Principal No. 2 said that:

"No, because there are two science labs against 1,247 students are insufficient. Small computer lab for up to 10 students is inadequate." (Field note on 1/07/2019).

In line with the findings of the study, Omego and Simatwa (2015) found out that inadequate laboratory was a significant factor contributing to poor performance in sciences and mathematics in secondary schools in Kisumu East Sub County. A lot of science is taught theoretically. This has led to failure in KCSE exams where some students are forced to tackle practical papers for the first time.

With regard to co-curricular activities, $96(60.8 \%)$ of respondents strongly disagreed that playgrounds had been expanded to include various sport activities after their schools were upgraded. This shows that majority of schools still utilise the same facilities that they had before they were upgraded thereby limiting majority of students for co-curricular activities. With regard to dormitory expansion and increase, 86 (54.4\%) strongly disagreed, $34(21.5 \%)$ disagreed, $18(11.4 \%)$ were undecided, 12 (7.6\%) agreed and $8(5.1 \%)$ strongly agreed. The above findings confirms that majority of students sleep in overcrowded dormitories $(\mathrm{M}=1.87$ and $\mathrm{SD}=1.18)$ which could pose health and security risk in case of emergency. In this case, some respondents admitted that their dorms that 
are there are not up to the required standards of Ministry of Education. The lack of adequate dormitory facilities could also explain the less desire by students from the area to join these schools even after upgrading.

On provision and adequacy of washrooms after upgrade, most teachers 78 (49.4\%) strongly disagreed that they were available and only 16 (10.1\%) appeared to indicate that bathrooms, latrines and toilets were constructed to meet the demand of their new status in the eight schools. When there exist inadequacy in sanitation facilities, incidents of health risks are high thereby putting the life of students at risk. In line with the study findings, Omegoa and Simatwa (2015) found out that toilets were inadequate, and this meant that a lot of time was wasted in lining up by students to relieve themselves, Class time was at times eaten into as student's queue waiting for each other to use the toilet. On whether the dining hall was expanded or new ones built, $104(65.8 \%)$ strongly disagreed, 20 (12.7\%) disagreed, 24 (15.2\%) were undecided, 4 (2.5\%) agreed and $6(3.8 \%)$ strongly agreed. This shows that majority of teachers disagreed with the statement $(\mathrm{M}=1.65$ and $\mathrm{SD}=1.06)$. The situation was worse in a school visited during the month of May where students were eating their meal under a tree while others as a result of rainy season did take their lunch and breakfast inside the classroom.

On seating and writing facilities, $76(48.1 \%)$ of teachers strongly disagreed that there was provision of enough lockers, tables and other classroom facilities had been increased after the upgrade. In most cases, parents enrolling their children to form one are required to come or purchase lockers for their students to bridge the shortfall that currently exists in schools. When these schools have inadequate lockers, tables, chairs and other classroom facilities, lesson instruction cannot be effectively conducted. Moreover, the students have to share these resources thereby compromising the quality of secondary education being provided in those institutions. Research also showed that most teachers strongly disagreed $78(49.4 \%)$ that their school land was expanded and areas that were not properly used put into use in their schools. the result confirms that despite the upgrade, the school land size of majority of them were not increased thereby affecting further development of infrastructural facilities in them. This could explain the reason as to why majority of schools did not put-up adequate facilities as a result of lack of space to put up such structures. The researcher found out that almost all schools needed more land to set up infrastructure and other facilities like playing ground in the school.

On whether their institutions added the fleet of their vehicles (especially buses), 74 (46.8\%) strongly disagreed, 40 (25.3\%) disagreed, 14 (8.9\%) were undecided, 18 (11.4\%) agreed and $12(7.6 \%)$ strongly agreed. This shows that most schools have maintained the current number of their fleet even after the upgrade. The lack of adequate means of transport did in some way affect school operations and also transport of students to academic visits and sport tournaments. Composite values shows that majority of teachers disagreed $(\mathrm{M}=1.88$ and $\mathrm{SD}=1.17)$ that new infrastructural resources were set up after their institutions were upgraded to national status. This shows that no major facility improvements or uplifts were dedicated to the eight upgraded national schools in the 
four counties of western Kenya. In line with the study results, Omego and Simatwa (2015) noted that physical facilities were rated at 4 by majority $388(53.6 \%)$ which meant that they were often a challenge to principals in their endeavours to enhance student academic achievement in Kisumu East Sub county.

The hypotheses for the study stated that:

$\mathbf{H}_{0}$ : There is no significant relationship between infrastructural resource dynamics and performance of upgraded secondary schools in Western Kenya Counties

$\mathrm{H}_{\mathrm{a}}$ : There is a significant relationship between infrastructural resource dynamics and performance of upgraded secondary schools in Western Kenya Counties

To test the hypothesis, a Karl Pearson correlation coefficient was computed at 95.0\% confidence level. The results are given in Table 2 .

Table 2: Infrastructure Resource Dynamics and Performance of Upgraded National Schools

\begin{tabular}{|l|l|c|c|}
\hline & & $\begin{array}{c}\text { Infrastructure } \\
\text { dynamics }\end{array}$ & $\begin{array}{c}\text { Performance } \\
\text { after }\end{array}$ \\
\hline \multirow{2}{*}{$\begin{array}{l}\text { Infrastructure } \\
\text { dynamics }\end{array}$} & Pearson Correlation & 1 & .063 \\
\cline { 2 - 4 } & Sig. (2-tailed) & & .432 \\
\cline { 2 - 4 } & $\mathrm{N}$ & 158 & 158 \\
\hline \multirow{2}{*}{$\begin{array}{l}\text { Performance } \\
\text { after }\end{array}$} & Pearson Correlation & .063 & 1 \\
\cline { 2 - 4 } & Sig. (2-tailed) & .432 & 158 \\
\cline { 2 - 4 } & $\mathrm{N}$ & 158 & \\
\hline
\end{tabular}

Result shows that there exist no significant relationship $(\mathrm{r}=0.063$ and $\mathrm{p}=0.432)$ between infrastructure resource dynamics and performance of upgraded national schools in the western region of the country. The null hypothesis $\left(\mathrm{H}_{0}\right)$ is accepted $(\mathrm{p}>0.05)$ and the alternative hypothesis is rejected $\left(\mathrm{H}_{\mathrm{a}}\right.$ ) leading to the conclusion that there exist no significant relationship between infrastructural resources planning dynamics and performance of upgraded extra county schools to national status in western Kenya. This statistic suggests that even after the upgrade, it happened only on paper and the elevation did not result to improvement and expansion of facilities and therefore have minimal impact on performance of schools in different areas presented early. The study is different from Lasoi et al. (2017) who found out that management of school physical resources influences school mean scores. The inadequacy of physical resources in schools is a major factor responsible for learning outcome of students.

\section{Conclusions and Recommendations}

Majority of teachers indicated that the average class size had increased by more than $50 \%$ and this did not correspond to classroom facilities available (lockers and tables). In terms of facilities expansion and construction of new facilities, most projects initiated in schools had stalled for more than five years thereby not benefiting the learners enrolled in them. This made many learners not to consider applying for such schools during selection processes. Even land for co-curricular activities was found not to have expanded as the 
focus seemed on academic (classroom matters). A comparison of infrastructure dynamics and institutional performance displayed exist of no significant correlation $(p>0.05)$. This implied that infrastructure facility dynamics did not in one way or another result to increase of institutional performance in the western region counties of Bungoma, Kakamega, Vihiga and Busia. The study recommends that there is need for schools to consider stakeholder consultation when planning for projects. There is also need for schools to have a workable plan through which it will guide on the infrastructural projects to be prioritised first before moving to others.

\section{Conflict of Interest Statement}

None.

\section{Acknowledgement}

This research did not receive any specific grant from funding agencies in the public, commercial, or not-for-profit sectors.

\section{References}

Andiema, N. C., Kemboi, G. C. \& M'mbone, J. (2013). Relationship between play activities' implementation and learners' academic performance in public early childhood development centres in West Pokot County, Kenya. Journal of Education and Practice, 4(26), $132-142$.

Ahawo, H. (2009). Factors Enhancing Student Academic Performance in Public Mixed Day Secondary Schools in Kisumu East District Kenya. Unpublished M.ED Thesis, Maseno University.

Best, M. (2005). Building Educational Success Together. Introduction. Retrieved from www.21csf.org/csf-home/best/best.asp on $5^{\text {th }}$ May, 2014 at $2.00 \mathrm{pm}$.

Chimombe, T. R. (2011). An analysis of biodiversity on fallow land in Chivi District, Zimbabwe. Bsc. Thesis, University of Zimbabwe.

Lasoi, J. C., Okoth U. \& Nelson, M. (2017). Board of Managements' Initiatives Influencing Quality Education in Secondary Schools in Kajiado, Kenya. Journal of Education, 1(3), $11-25$.

Lucas, A. M. \& Mbiti, I. M. (2014). Effects of School Quality on Student Achievement: Discontinuity Evidence from Kenya, American Economic Journal: Applied Economics, American Economic Association, 6(3), 234-263.

Lumuli, N. C. (2009). An Investigation into Internal Efficiency Measures in Promotion of Access and Completion Rates in Public Secondary Schools in Bungoma South District. Unpublished MED Thesis, University of Nairobi.

Mobegi, F., Ondigi, B., \& Oburu, P. (2010). Secondary school head teachers' quality assurance strategies and challenges in Gucha district, Kenya. Educational Research and Reviews, 5(7), 408- 414. 
Ogada, P. O. \& Simatwa, E. M. (2016). Factors influencing Dropout of Pupils in Public Primary Schools in Kenya: A Case Study of Kakamega Municipality. International Journal of Current Research, 8(07), 34503-34512.

Ogot, O. (2008). Making Primary Education Meaningful and Inclusive: A study in Kenya. Paper presented at UNECA/LCD Conference, Addis-Ababa, $20^{\text {th }}-22^{\text {nd }} M a y$.

Ogunniyi, S. O., Lawal, W. O. \& Sheji, M. R. (2018). Assessment of Resources in Selected Secondary Schools Library Media Centres in Ondo, Ondo State. Library Philosophy and Practice (e-journal), 1667. Retrieved on $2^{\text {nd }}$ March 2018 at https://digitalcommons.unl.edu/libphilprac/1667.

Okumbe, J. A. (2011). A Study of the Impact of the centre for Corporate Governance Training Programmes on Corporate Governance Practices by Kenyan Corporations. Nairobi: University of Nairobi.

Olatunde, P. Y., \& Omondi, K. O. (2010). Teaching/Learning Resources and Academic Performance in Mathematics in Secondary Schools in Bondo District of Kenya. Asian Social Science, 6(12), 126-132.

Ongowo, R. O. \& Indoshi, F. C. (2013). Science Process Skills in the Kenya Certificate of Secondary Education Biology Practical Examinations. Creative Education, 4(11), 713-717.

Owoeye, J. S. \& Olatunde, P. Y. (2011). School facilities and academic achievement of secondary school agricultural science in Ekiti State, Nigeria. Asian Social Science, 7(7), 64-74.

Waweru, P. N. \& Orodho, A. J. (2013). Management practices and students' academic performance in national examinations in public secondary schools in Kiambu County. International Journal of Scientific Research, 5 (2), 472-479.

Wakoli, M. \& Kisilu, K. (2019). Principals Administrative Strategies and Academic Performance of Public Secondary Schools in Mount Elgon Sub County, Bungoma County, Kenya. IJRDO - Journal of Educational Research (ISSN: 2456-2947), 4(11), 10 20. Retrieved from http://www.ijrdo.org/index.php/er/article/view/3322.

Waweru, S. N. (2005). Instructional Supervision. Retrieved online at www.ku.ac.ke/samuel.wererupdf.

Wekesa, V. \& Kitainge, K. M. (2020). Human resource planning dynamics and academic performance of upgraded national schools in Western Kenya Counties. European Journal of Education Studies, 7(7), 376-391. DOI: http://dx.doi.org/10.46827/ejes.v7i7.3179. 
Creative Commons licensing terms

Author(s) will retain the copyright of their published articles agreeing that a Creative Commons Attribution 4.0 International License (CC BY 4.0) terms will be applied to their work. Under the terms of this license, no permission is required from the author(s) or publisher for members of the community to copy, distribute, transmit or adapt the article content, providing a proper, prominent and unambiguous attribution to the authors in a manner that makes clear that the materials are being reused under permission of a Creative Commons License. Views, opinions and conclusions expressed in this research article are views, opinions and conclusions of the author(s). Open Access Publishing Group and European Journal of Education Studies shall not be responsible or answerable for any loss, damage or liability caused in relation to/arising out of conflicts of interest, copyright violations and inappropriate or inaccurate use of any kind content related or integrated into the research work. All the published works are meeting the Open Access Publishing requirements and can be freely accessed, shared, modified, distributed and used in educational, commercial and non-commercial purposes under a Creative Commons Attribution 4.0 International License (CC BY 4.0). 